The legacy of subalternity and

Gramsci's national-popular: populist

discourse in the case of the Islamic

\title{
Republic of Iran
}

\author{
Holliday, Shabnam
}

http://hdl.handle.net/10026.1/4570

10.1080/01436597.2015.1113872

THIRD WORLD QUARTERLY

Informa UK Limited

All content in PEARL is protected by copyright law. Author manuscripts are made available in accordance with publisher policies. Please cite only the published version using the details provided on the item record or document. In the absence of an open licence (e.g. Creative Commons), permissions for further reuse of content should be sought from the publisher or author. 
This is an Accepted Manuscript of an article published by Taylor and Francis in Third World Quarterly, April 2016 available at:

http://www.tandfonline.com/doi/abs/10.1080/01436597.2015.1113872?journalCode=ctwq20.

\author{
The Legacy of subalternity and Gramsci's national-popular: populist discourse in the \\ case of the Islamic Republic of $\operatorname{Iran}^{1}$
}

Shabnam J. Holliday ${ }^{2}$

\begin{abstract}
Drawing on Laclau's concept of populist discourse and Gramsci's 'national-popular collective will', and using the case of Iran, this article puts forward the idea of legacy of subalternity in the context of post-revolution governments. The concept of 'national-popular collective will' facilitates an understanding of how the popular subject is constructed and the meanings embedded in that process. It is argued that Islamic Republic elites articulate a populist discourse that constructs the 'self' (the Islamic Republic) as synonymous with 'the people'. Embedded in this discursive construction is a legacy of subalternity that goes back to the 1979 Revolution's populist discourse.
\end{abstract}

Key words: Gramsci, subaltern, populism, Iran, Rouhani, national-popular

\title{
Introduction
}

The true presence of people in the Islamic Republic, their role in electing officials and safeguarding the outcomes of the Islamic Revolution, are themselves symbols of the truthfulness of the Islamic regime and its being of the people. ${ }^{1}$

The key is the presence and the support of the people. Of course, also, the government works as the servant of the people and as someone who is the agent of the people. ${ }^{2}$

The first text presented above is by Iran's Supreme Leader Ayatollah Ali Khamenei (1989-to present) taken from Questions and Answers in the Presence of the Supreme Leader published in 1380/2001- $2^{3}$. This text explicitly constructs the 'the people' as an integral part of the Islamic Revolution and the Islamic Republic. The second text, by President Hassan Rouhani, is taken from a television interview given 100 days after his election. In this interview Rouhani is asked whether he has the 'key' to solving the 'lock' of the nuclear issue. Rouhani's response is that it is 'the people' that have the key ${ }^{4}$. It is evident here that both texts from these members of Iran's ruling elite ${ }^{5}$ prescribe a particular relationship between the 'rulers' and the 'ruled'. For these 'rulers' it is clear that the Islamic Republic is chosen by 'the people' and is for 'the people'. For Khamenei, this is reflected in his use of 'mardumi',

\footnotetext{
${ }^{1}$ Acknowledgements: This paper was developed while I was a Visiting Scholar with the University of Exeter's Political Theory Group in the autumn of 2014. Earlier versions have been presented at Exeter's Political Theory Reading Group, Plymouth University's PISC Seminar Series and at the SeSaMO Conference, Venice in January 2015 and I am grateful for these opportunities to present. I would like to thank Robert Lamb, Dario Castiglione, Paola Rivetti, Adrian Holliday and the anonymous reviewers for their very helpful comments.

${ }^{2}$ School of Government, Plymouth University, Plymouth, UK. Email: shabnam.holliday@ plymouth.ac.uk
} 
literally 'of the people'; and for Rouhani this is reflected in the construction of 'the people' as a political actor.

My argument is three-fold. Firstly, drawing from Ernesto Laclau's concept of populist discourse, it is argued here that these texts are indicative of a populist discourse wherein 'the people' are constructed as a political actor, and indeed as a popular subject. Additionally, the Islamic Republic constructs itself as synonymous with this popular subject: 'the people'. Significantly, 'the people' represents a legacy that directly links the current Islamic Republic to the populist discourse of Ayatollah Ruhollah Khomeini at the time of the 1979 Revolution.

Secondly, it is contended that a borrowing of Antonio Gramsci's notion of the 'national-popular' facilitates an understanding of the way in which the 'self' is constructed as well as the meanings embedded in that process of construction. In this particular instance, the idea of the 'national-popular collective will' symbolises the populist discourse of the Islamic Republic and the continuing legitimacy of Khomeini's Islamic Republic. In Gramscian terms, the establishment of the Islamic Republic following the 1979 Revolution is an example of subaltern groups successfully overthrowing the state hegemon and establishing themselves as the hegemon because they had the 'national-popular collective will'. Thus, the 'nationalpopular collective will' symbolises the importance of the legacy of subalternity.

Consequently, the populist discourse of the Islamic Republic's ruling elite illustrates what is essentially a post-subaltern hegemonic populist discourse that reflects a binary hegemonic relationship between the 'self' and the 'other'. The 'self' is the Islamic Republic which constructs itself as synonymous with the people. The 'other' is anything that poses a threat to the Islamic Republic's legacy of subalternity and its position as beholder of the 'nationalpopular collective will'.

Finally, I argue that Rouhani's presidential candidacy in 2013 represents an attempt to regain the 'national-popular collective will' and restore the Islamic Republic's legacy of subalternity following the 2009 presidential election. Subsequently, this reinstates the Islamic Republic's populist credentials as well as its legitimacy. The notion of the 'national-popular collective will' is crucial to understanding the relationship between the 'rulers' and the 'ruled'. Ultimately, this analysis of populism advocates a bringing together of Laclau's populist discourse and Gramsci's 'national-popular collective will'. It is suggested that this combination can be used as a framework for looking at and deconstructing populism in postrevolutionary situations. These are situations of post-subaltern hegemony where the legacy of subalternity justifies and legitimises the status of hegemony.

In order to understand the significance of Gramsci's 'national-popular collective will' in the case of Iran, two particular historical moments need to be addressed: the 1979 Iranian Revolution and the controversial 2009 presidential election. In brief, leading up to the 1979 Revolution, Khomeini and his understanding of Shi'ite political Islam were successful in overturning the Pahlavi regime, arguably because he managed to embrace the 'nationalpopular collective will'. By forcing Mohammad Reza Pahlavi Shah into exile, the 1979 Iranian Revolution is an example of a process whereby the subaltern successfully overturned hegemony because of the presence of the 'national-popular', as will be illustrated below.

The tenth presidential election was controversial because in June 2009 the incumbent President Mahmoud Ahmadinejad was re-elected for his second and last term amidst claims of electoral fraud ${ }^{7}$ and popular uprisings ${ }^{8} .2009$ demonstrated the failure of Ahmadinejad's 
populism ${ }^{9}$, and indeed Khamenei found himself in a crisis of authority and the legitimacy of Islamic Republic was questioned ${ }^{10}$. The extent of popular discontent evident in the popular uprisings represented a failure to embrace the 'national-popular collective will' and thus posed a threat to the Islamic Republic's populist credentials. As far as Khamenei and Ahmadinejad (as well as their supporters) were concerned, there appeared to be an 'other' that threatened the Islamic Republic's identity as the beholder of the 'national-popular collective will'. This 'other' was essentially constructed as a threat to the Islamic Republic's construction of itself as 'the people', and subsequently also threatened its legitimacy.

It should also be mentioned that in addition to the clear threat to the Islamic Republic as the beholder of the 'national-popular collective will', there were other interlinked political dynamics that can account for Rouhani's candidacy, and ultimately his election. The first is intra-regime political battles; during Ahmadinejad's presidency rifts among the conservatives had come to replace the divisions between the conservatives and reformist as the most publicised political battle. ${ }^{11}$ The second is Iran's deteriorating economic situation caused by a combination of Ahmadinejad's economic policy and the 'growing, cumulative effects of the sanctions ${ }^{\prime 2}$, which were imposed by the UN, EU and the US in response to Iran's nuclear programme. The third is the desire within the regime and by many Iranians for Iran to come out of international isolation ${ }^{13}$. Thus, by the time of the 2013 presidential election, Khamenei needed to 're-build the regime's legitimacy.' ${ }^{14}$ In the context of protests and uprisings elsewhere in the region, Khamenei also needed to avoid further protests that could threaten the stability of the regime, and restore the centrality of clerical rule as opposed to the influence and power of military rule in the form of the Iranian Revolutionary Guard Corp (IRGC) ${ }^{15}$. While he wanted the reassertion of conservative dominance and permitted Rouhani's candidacy, Rouhani's election was not his preferred choice ${ }^{16}$. However, Khamenei had to submit to popular will and Rouhani was Khamenei's best option for restoring the regime's legitimacy ${ }^{17}$.

This popular will is reflected in Rouhani's popular mandate. Rouhani was elected as president on 13 June 2013 by just over 50 per cent of those who turned out to vote. ${ }^{18}$ He was popular in the provinces winning all the major provincial cities, and considerable support from ethnic minorities ${ }^{19}$. Furthermore, for many Iranians it was case of voting for Rouhani so as to prevent a conservative candidate from winning ${ }^{20}$. While Rouhani is labelled moderate, centrist, even reformist in some instances, he cannot be considered as anything other than part of the Islamic Republic's regime and part of the establishment. The popular mandate coupled with a mandate from above puts Rouhani in a unique and significant position ${ }^{21}$. It is in this context that Rouhani can be considered as an effort to reinstate the Islamic Republic's populist credentials and its legacy of subalternity.

It must be stressed that while 'the people', or the 'national-popular collective will', are constructed here by Islamic Republic elites as a monolithic entity, in reality this is far from the case. Iran is a multi-ethnic and multi-religious state ${ }^{22}$. In addition to this, there are a variety of aspirations regarding the nature of politics in Iran. In some instances this is translated into desires for substantial political change, which was clearly evident in $2009^{23}$. Among the political groups and movements involved in demanding various levels of political change are members from the women's movement, labour movement, students' movement and human rights activists. Notably, each of these groups is also diverse in their make-up and 
political aspirations. In other instances the variety of political aspirations is evident in desires for reform from within the regime. Indeed, not only can the Iranian population not be considered simply in terms of 'the people', neither can 'the state' be considered as a monolithic entity, and is often shown to be fragmented ${ }^{24}$, as the above depiction of the 2013 election shows.

The article will first address Laclau's populist discourse and Gramsci's 'national popular'. It will then go on to illustrate how the Islamic Republic continues to construct itself as 'the people' and the beholder of the 'national popular collective will' and aims to maintain its legacy of subalternity through the candidacy of Rouhani.

\section{Populist discourse and Gramsci's national-popular}

A number of studies note the contested nature of the concept of populism and the exceptional vagueness of the term ${ }^{25}$. This ambiguity is reflected in how populism is perceived. In brief, on the one hand, populism is considered as a movement and/or an ideology in the same way that liberalism, socialism, and 'Third Worldism' are understood as movements and/or ideologies ${ }^{26}$. This approach is rejected by Laclau and those who build upon his discursive approach to populism ${ }^{27}$. Rather than dwelling on the vagueness of populism, Laclau suggests considering whether this vagueness is due to the "consequence of a social reality itself being in some situations, vague and undetermined ${ }^{28}$. He also poses important questions about the ideology/movement approach: can ideology and movement be separated ${ }^{29}$; to what extent can they be considered populist ${ }^{30}$; and for what social and ideological reality does populism apply $^{31}$. In response to his own questions Laclau asserts that there is populist discourse and that ideologies and movements can reflect populist discourse, albeit to varying degrees ${ }^{32}$.

Importantly, for Laclau discourse exists in 'any complex elements in which relations play the constitutive role.' He argues that 'This means that elements do not pre-exist the relational complex but are constituted through it. ${ }^{33}$ In other words, elements, such as 'the people', only exist in so far as they are constructed as such through the articulation of discourse. And, it is 'the people' that reflects populism or the articulation of populist discourse $^{34}$. As Francisco Panizza argues, populism is based on the constitution of the people as a political actor and thus, 'the people' is established as the 'concept's analytical core' ${ }^{35}$. Indeed, 'we only have populism if there is a series of politico-discursive practices constructing a popular subject ${ }^{36}$. Crucially, the precondition of the emergence of the construction of a popular subject is 'the building of an internal frontier dividing the social space into two camps ${ }^{37}$ that is enforced by the constructed binary relationship between the politically constructed 'self' and 'other'. For Panizza, this is 'constituted through the relation of antagonism, ${ }^{38}$. In this relationship, the 'people' (the 'self') are constructed as the 'underdogs ${ }^{39}$ in relation to a hegemonic 'other'. This was clearly evident in both 1979 and following the results of the 2009 presidential election. In 1979, through the articulation of Khomeini's populist discourse, 'the people', constructed as the 'self', were in a relation of antagonism with the Pahlavi regime, constructed as the hegemonic 'other'. In 2009, members of the ruling elite through their own discourse of populism built an internal frontier that divided the social space of Iran's political arena into two camps. The ruling elites such as Khamenei and his supporters, who perceived themselves as synonymous with 'the people' were the legitimate 'self'. Meanwhile, those protesting against the re-election of 
Ahmadinejad were constructed as the 'other" ${ }^{40}$ : a hegemonic force that was a threat to 'the people' and therefore the Islamic Republic's legacy of subalternity. It is contended that the candidacy of Rouhani in 2013 is an attempt to diffuse this antagonism and co-opt the hegemonic 'other'.

Gramsci's notion of the 'national-popular collective will' enables a better understanding of the nature of the antagonistic relationship between the 'self and 'other'. This is because it facilitates an understanding of the meanings embedded in the process of constructing the 'self'. It is contended that the populist discourse of members of the Islamic Republic's ruling elite constructs 'the people' as a popular subject at the same time as constructing the 'self' as 'the people'. In addition to this, by constructing the 'self' in this way, it is essentially constructing the 'self' as the beholder of the 'national-popular collective will' and asserting its legacy of subalternity. However, as noted above, the analysis here borrows Gramsci's notion of 'national-popular collective will'. A strict adherence to Gramsci's notion is problematic. After all, a strict application of a concept that is created in relation to a particular historical experience (the desire to overthrow fascism through a communist revolution in Italy) to another historical experience (Iran's 1979 Revolution) is problematic. Thus, Gramsci's 'national-popular collective will' is analysed in conjunction with the 1979 Revolution.

While it is important to note that the revolutionary movement that led to the end of the Pahlavi regime was composed of a multitude of factions and groups reflecting a multitude of ideologies and political aspirations regarding post-Pahlavi $\operatorname{Iran}^{41}$, it was ultimately Khomeini and those that followed him that secured the future of Iran. Arguably this was because it was his populist discourse that held the 'collective will' of the 'national-popular'. Once Mohammad Reza Shah was forced into exile in January 1979, a referendum on changing the country's political system to an Islamic Republic was prepared ${ }^{42}$. Baqer Moin notes that in the weeks following the Revolution those who were opposed to the idea of the Islamic Republic 'could expect to suffer damaging consequences'; thus, it was not surprising that 'on 30 and 31 March, 97 per cent of the electorate, including most of the secularist political organisations, voted "yes" to an Islamic Republic" ${ }^{43}$. This was the embodiment of Khomeini's Vilayat-i Faqih (Guardianship of the Jurist), an ideology that was developed in the 1960s, disseminated through tapes and published in 1970 in his book Hukumat-i Islami (Islamic Government). ${ }^{44}$ Despite the pressure to vote 'yes', the referendum is upheld as evidence for the popularity of the Islamic Republic being of 'the people' 45 , and therefore its populist credentials and its legacy of subalternity.

This historical context helps make sense of the employment of Gramsci's nationalpopular in the context of how Islamic Republic 'rulers' perceive their relationship with the 'ruled', and the way in which the 'self' is constructed. Gramsci argued that in order for revolution to take place three elements need to be present: a 'modern prince', an alliance including the masses (the subaltern groups), and intellectual, cultural and moral reform of the masses. These three elements together constitute the "national-popular collective will" ${ }^{46}$. The modern prince's role is crucial. He is responsible for proclaiming and organising 'an intellectual and moral reformation' that will facilitate the appropriate environment for the 'subsequent development of the national-popular collective will towards the realization of a superior, total form of modern civilization. ${ }^{47}$ Ultimately, revolution comes about when 
subaltern groups (Iranian masses) overthrow the hegemon (Pahlavi regime), and establish themselves as the new hegemon (the Islamic Republic), while maintaining the 'nationalpopular collective will'. Hegemony is understood here as economic, political, intellectual and moral leadership. In this regard, Gramsci states that in order for a dominant group to gain hegemony over subordinate groups, it is necessary to bring about 'not only a unison of economic and political aims, but also intellectual and moral unity': 'the supremacy of a social group manifests itself in two ways, as "domination" and as "intellectual and moral leadership". ${ }^{48}$

The term 'subaltern' can be used to represent those groups in society that are marginalised by or subjected to the hegemon or dominant group. While it is not a concept that is systematically analysed in Gramsci's work ${ }^{49}$, it is clear that Gramsci is not necessarily simply referring to a single group in society. It is used to refer to non-commissioned military groups, those in positions of subordination, and finally to social class ${ }^{50}$. In a discussion of the Catholic Church Gramsci refers to 'the subaltern intellectual stratum (primary and secondary school teachers, priests etc.) ${ }^{, 51}$ The subaltern is also implicit in Gramsci's references to rural masses and the popular masses ${ }^{52}$. The role of the subaltern is fundamental in the process of revolution because without them revolution cannot take place. This is because the "nationalpopular collective will' cannot be achieved without the inclusion of the masses, the subaltern groups in society, which are to burst 'simultaneously into political life' ${ }^{53}$ Indeed, this awakening and development of a 'national-popular collective will' exists when there is a 'Jacobin force' as there was during the French Revolution ${ }^{54}$. Thus, as David Forgacs notes, 'a national-popular movement is one in which a fundamental class becomes hegemonic at a national level by drawing subaltern social groups into an alliance. ${ }^{, 55}$

It can be debated whether or not those in favour of the 1979 Revolution were strictly speaking, in the Gramscian sense, the 'subaltern'. Indeed, the importance of class in Gramsci's analysis suggests that it cannot be applied to the Iranian case because it was not only 'rural' and 'popular masses' that were involved; the revolution was also very much urban with the middle classes playing a crucial role. ${ }^{56}$ It is this issue of class that divides Marxist and post-Marxists in their view of Gramsci. Unsurprisingly post-Marxists are critiqued because they feel class is fundamental to Gramsci's analysis and therefore Gramscian analysis ${ }^{57}$. Whereas those who follow Laclau, feel that class does not need to be at the centre of the notion of hegemon. Indeed, the hegemonic project has 'ceased to have any necessary link with class ${ }^{, 58}$. Furthermore, 'Laclau extends the logic of non-class belonging or contingency to all political discourses ${ }^{, 59}$. Thus, in this instance the subaltern is understood as those who saw themselves as marginalised by and subjected to the hegemony of the Pahlavi regime. This is not necessarily linked to class.

As noted above, the 'national- popular collective will' shall lead to a 'total form of modern civilization'. Epifanio San Juan notes that 'Gramsci envisioned the "nationalpopular" as a process of lay intellectuals expanding and elaborating a secular "humanism" attuned to the grassroots ${ }^{, 60}$. The point here is whether a religious movement can be considered modern, when here modernity is associated with a secular project. The aim of establishing an Islamic republic is clearly not secular. Nevertheless, the 'modernity' of the 1979 Revolution and parallels with secular revolutions has been highlighted on a number of occasions. Ramin Jahanbegloo argues that rather than perceiving the transformation of a Shi' $i$ 
hierocracy into a political regime as an "irreconcilable clash between "tradition" and "modernity", it should be considered more in terms of 'a series of ontological and anthropological encounters between the two ${ }^{, 61}$. For Ervand Abrahamian, 'Khomeinism' had more in line with Latin American populism than the Shi' $i$ tradition ${ }^{62}$. This resemblance was evident in the middle-class nature of the movement, which 'mobilized the masses with radical-sounding rhetoric against the external powers and the entrenched power-holding classes ${ }^{63}$. Populism was reflected in the language used 'against the ruling elite'; it also "claimed to be a "return to native roots" and a means for eradicating "cosmopolitan ideas" and charting a noncapitalist, noncommunist "third way" toward development. ${ }^{, 64}$ Larry Ray contends that the 'Islamic fundamentalism' of the 1979 Revolution can be considered as a 'form of modernist revolutionary populism'. He suggests a parallel between the 1979 Revolution and the French Revolution's Jacobin phase ${ }^{65}$; a parallel also asserted by Nikki Keddie and Ali Ansari. ${ }^{66}$ The 1979 Revolution's 'modernity' is also evident in the nationalist character of the Revolution. To this end, Ansari argues that 'it took religious nationalism to free Iranian nationalism from its elite pretensions and make it popular.' And, it was 'religious nationalism' that was evident in the 1979 Revolution ${ }^{67}$. Thus, the Islamic aspect of the Revolution does not take away from its 'modernity'.

Simply having the subaltern on board is insufficient in establishing a 'nationalpopular collective will'. This is because, if the hegemony of the subaltern group is to be achieved, there must be the moral, intellectual and cultural reform of the masses; and it is the modern prince that is to carry out the reform. For Gramsci, 'The modern prince, the myth prince, cannot be a real person, a concrete individual'; rather, it can only be organism, a complex element of society'. This organism is the political party ${ }^{68}$. In the case of the 1979 Revolution, there was not a 'political party' in the Gramscian sense. While there were several ideas represented by different groups and factions being articulated through various discourses, as noted above, that which championed and was able to establish itself as a hegemon was the populist discourse and ideas of a single figure, namely Khomeini. Gramsci presents an image of the modern prince in 'State and Civil society' that is more open than that portrayed in 'The Modern Prince'. Here, in addition to being a head of state, or leader of government, Gramsci states that the "Prince" could also be 'a political leader whose aim is to conquer a State, or found a new type of State ${ }^{, 69}$. While Khomeini and his followers may not qualify as a political party, they certainly do fit with this more open understanding of the modern prince.

The contention advocated by Quintin Hoare and Geoffrey Nowell Smith that the idea of nation-popular is cultural rather than political would also make the use of the nationalpopular put forward here problematic. They argue that the national-popular 'is a cultural concept, relating to the position of the masses within the culture of the nation, and radically alien to any form of populism or "national socialism", 70 . My response to this is three-fold. First, the way in which they view populism, as a particular ideology akin to "national socialism', is problematic. Rather, it should be considered in terms of discourse that constructs 'the people' as a popular subject in opposition to an 'other', as illustrated above. The second points relates to the role of the masses in relation to the desire for hegemony. Hoare and Nowell Smith's contention suggests that establishing a culture for a nation is not a political project. However, if there is to be a national-popular culture, the very act of creating 
one is a political project in itself. Related to this, is the third point. In the case of Iran, arguably Khomeini's political aspiration was made possible through the cultural and intellectual reform of the masses by means of disseminating his understanding of Islam. Importantly, the culture of Islam was politicised in a particular way.

Overall, it is the process outlined by Gramsci that illustrates the significance of the populist discourse articulated by Islamic Republic elites. This process is symbolised by the significance of the 'national-popular collective will'. Each hegemon has its own moral, political and intellectual leadership and in turn has subaltern groups being marginalised by that particular hegemony. The process of political transformation outlined by Gramsci, that is the role of the modern prince to bring about a national-popular collective will that brings together the subaltern masses by means of cultural, intellectual and moral reform, helps explain the importance of 'the people' in bringing about revolution. They are constructed as a popular subject. So while Gramsci's analysis is positioned in a particular historical experience, the process of political transformation can be applied to other historical or indeed contemporary experiences.

In the case of contemporary Iran, Gramsci's concept of 'national-popular collective will' highlights a historical trajectory that allows us to examine the most recent stage in a particular political transformation: a political system that exists 35 years after the revolution and is adamant in displaying its populist credentials through its legacy of subalternity. This is a situation of post-subaltern hegemony. This framework helps explain the process of a populist discourse transforming from one that is subaltern into a one that is hegemonic. It is the process following this political transformation that is now of interest.

\section{Populist discourse: The Islamic Republic as 'the people'}

The populist discourse articulated by Islamic Republic ruling elites, such as Khamenei and Rouhani, is undoubtedly a means of legitimising the position of the Islamic Republic as hegemon in the state. Furthermore, in order maintain its legitimacy it needs to uphold its legacy of subalternity. To do this, the ruling elites need to ensure that the Islamic Republic continues to be the beholder of the 'national-popular collective will' that facilitated the 1979 Revolution. However, as noted above, the popular uprisings following the re-election of the incumbent Ahmadinejad in 2009 threatened the status of the Islamic Republic as constructed by Khamenei, Ahmadinejad and their followers. Amongst the protestors were those in favour of the ideals of former President Mohammad Khatami (1997-2005) and presidential candidates Mir-Hussein Mousavi and Mehdi Karoubi, who called for the reform of the Islamic Republic ${ }^{71}$. Others rejected Vilayat-i Faqih altogether and advocated an end to the Islamic Republic ${ }^{72}$. Ansari argues that the regime's failure 'to get all Iranians to fall into line' behind the re-election of Ahmadinejad represented a crisis of authority ${ }^{73}$.

Nevertheless, in an attempt to maintain their legitimacy, and restore their authority, these ruling elites reasserted their populism by articulating a discourse that divided the social space of Iran's political arena into two groups; them and us. This division was enforced by constructing a binary relationship between the 'self' and the 'other'. In this case the 'self' was the Islamic Republic as constructed by Khamenei and Ahmadinejad along with their supporters. Here the 'self' was constructed as the legitimate representative of 'the people'. The 'other' was those who were involved in the protests against the election of Ahmadinejad. 
Khamenei condemned the protests, accusing the protestors of being the tools of foreign enemies and consequently a threat to the Islamic Republic ${ }^{74}$. While the uprising was essentially popular, protestors were delegitimised by being constructed as the tool of foreign enemies that were intent on destroying the Islamic Republic from within. They were a 'threat ${ }^{75}$. It is argued that in face of this perceived threat from the 'other', the Islamic Republic needed to reconstruct the 'self' in order to be able to convincingly articulate a populist discourse whereby it is the beholder of the 'national-popular collective will'. This process is represented by Khamenei allowing Rouhani to stand as president in 2013. It illustrates an attempt to recapture the 'national-popular collective will' and restore the Islamic Republic's legacy of subalternity.

Rouhani's presidential candidacy is symbolic because he was permitted to stand by Khamenei and supported by Khatami. Furthermore, as noted above, once Rouhani was elected Khamenei wanted to avoid further protests. In the aftermath of the 2009-10 popular uprising this suggests an attempt to bring the nation back together. Khamenei's support at the time was evident in allowing Rouhani to stand as president; candidates are only permitted to stand as president once they have been vetted by the Supreme Leader. Furthermore, Khamenei and Rouhani have worked closely together. Rouhani was 'Secretary of the National Security Council between 1989 and 2005 and accordingly served as the chief nuclear negotiator with the EU-3 group during Khatami's presidency ${ }^{\text {,76 }}$. It is perhaps not surprising, therefore that his candidacy was also supported and encouraged by Khatami.

Khatami's support is significant because of what Khatami represents in Iranian politics. Firstly, the ideals of Khatami's reformist presidency represent a more liberal understanding of the Islamic Republic than that of Khamenei. Under his administration, civil society expanded, the women's movement flourished and public society was relatively liberalised ${ }^{77}$. Indeed, he embarked upon 'expanding citizen's participation in the political domain ${ }^{, 78}$, or the "citizenisation of society ${ }^{79}$. Khatami's political Islam was a post-Islamist ${ }^{80}$ one that advocated mardumsalari-yi Islami (Islamic democracy). ${ }^{81}$ This was to be achieved through 'freedom, equality, and possession of rights' through which 'the people' are able to truly enjoy civil and political rights ${ }^{82}$. Also integral to Khatami's reformist agenda was 'dialogue among civilisations'. In terms of international politics, this meant that better and constructive relations between Iran and the 'West' were advocated as well as a move out of isolation. ${ }^{83}$ Secondly, Khatami was also instrumental in Mousavi’s 2009 presidential campaign against the incumbent Ahmadinejad, who was supported by Khamenei, as noted above. Finally, following the 2009-10 popular uprising Khatami is associated with Mousavi and Karoubi by those who reject reformist approaches to the Islamic Republic. In February 2011, Mousavi and Karoubi, and Zahra Rahnavard (Mousavi's wife who campaigned alongside him) were placed under house arrest. In this context Khatami is also associated with the rejection of Khamenei's construction of the Islamic Republic and consequently the hegemonic 'other' that threatens the populist and legitimate Islamic Republic.

With these issues in mind, Rouhani's candidacy demonstrates awareness that in 2009 the regime did not have the entire 'national-popular collective will' and that the 'self' was threatened by what was thought to be a potentially hegemonic 'other'. The implication of this is that the legitimacy of the Islamic Republic as constructed by Khamenei was threatened. In this context Rouhani acts as a means of ensuring the 'national-popular collective will' and 
thus restoring, ironically, the hegemony of the 'self', which is perceived to be the only legitimate government because of the role of the 'national-popular' in 1979.

Once elected, Rouhani's discursive construction of the Islamic Republic as a popular subject illustrates the continuation of a post-subaltern hegemonic populist discourse. We see the continued articulation of the Islamic Republic as 'the people' and the reassertion of the Islamic Republic's legacy of subalternity. On the surface, it would seem that Rouhani is articulating a similar discourse to Khatami, one that talks about human rights and his plans for a civil rights charter ${ }^{84}$. However, considering the continued existence of political prisoners ${ }^{85}$ and the continued house arrest of Mousavi, Karoubi and Rahnavard, it would also seem that Rouhani is not in favour of, or, unable to bring about an Islamic Republic that is more respectful of human rights. Rather, it is Rouhani's use of language associated with 'the people' that reflects a populist discourse taking its legitimacy from its legacy of subalternity as well as being elected by 'the people'.

This populist discourse, through the construction of 'the people' as a popular subject is reflected in the use of language. In particular, this is use of terms that invoke 'the people' such as muntakhib-i mardum (elected by the people), mardumi (of the people), and mardumsalari ('democracy' or rule by the people). They reflect a populist discourse whereby the Islamic Republic constructs the 'self' as 'the people'. Implicit in the terms mardumsalari, muntakhib-i mardum and mardumi are the belief that despite having succeeded in becoming the state government, the hegemon, the Islamic Republic maintains its position as the beholder of the 'national-popular collective will', and therefore its legacy of subalternity.

Rouhani's populist discourse is clearly articulated in the months following his election. On a number of occasions Rouhani talks about how his election represents the victory of the nation. For instance, in his first press conference he states that 'The nation was victorious ${ }^{86}$. He also goes on to explain in a number of ways how his election due to the great nation's participation in their numbers. ${ }^{87}$ This populist discourse is also articulated in response to a question from NBC's Ann Curry regarding Israel's Prime Minister Benyamin Netanyahu's description of Rouhani as a 'wolf in sheep's clothing' in his 2013 United Nations General Assembly speech. ${ }^{88}$ Rouhani responds by stating that 'an occupier and usurper government' such as Israel, 'shouldn't allow itself to give speeches about a democratically and freely elected government that has come about by means of the free votes of the people. ${ }^{89}$ This is in itself may not be significant. After all, it is not unusual for recently elected political leaders to highlight the popular nature of their election. Nevertheless, this discourse constructs the 'self' as 'the people' because it asserts that the Islamic Republic is once again of 'the people'. Furthermore, the way in which Rouhani positions his administration as one that is supported by Khamenei while subscribing to Khatami's reformism is significant. In doing this, Rouhani actively adopts his role of re-establishing the 'national-popular collective will'.

This significant positioning is explicit in Rouhani's statement of confirmation in the Supreme Leader's presence. Given on 4 August 2013, the day after he took office, Rouhani expresses particular concepts that position his 'government of hope and prudence' as one of moderation. The presence of Khamenei shows that the Supreme Leader, at least on this occasion, supports Rouhani's aspirations. However, he is also appealing to those Iranians who favour Khatami. He states: 
Moderation is an obvious characteristic of farhang-i Irani-Islami (Iranian-Islamic culture). Moderation is not a deviation from the foundations, nor does it demonstrate conservatism in the face of change and development. ... The way to continue and maintain mardumsalari-yi dini (religious democracy) is moderation. $^{90}$

In this text Rouhani cleverly attempts to bring down the constructed internal frontier between 'them' and 'us' in Iran's political arena. This is an attempt to reduce the relation of antagonism, and thus essentially restore the Islamic Republic as the beholder of the 'nationalpopular collective will'. Irani-Islami culture was a major pillar of Khatami's inclusive Islamist-Iranian discourse of national identity whereby both Iran's pre-Islamic Iranian culture and its Islamic culture were constructed as integral to the identity of the Iranian nation. ${ }^{91}$ However, by referring to mardumsalari-yi dini Rouhani is also addressing Khamenei's supporters; mardumsalari-yi dini is the term used by Khamenei for the Islamic Republic. ${ }^{92}$ Finally, the reference to 'foundations' and 'conservatism', suggests that Rouhani is addressing the conservative elements of the Islamic Republic. For Rouhani, his government of hope, prudence and moderation is the one that can bring all these elements together.

In terms of foreign affairs, Rouhani's notion of 'constructive engagement' harks back to Khatami's 'dialogue among civilisations', which was very popular among his supporters. In this context Khatami's support for Rouhani is explicit. In September 2013, Khatami stated that 'president Rouhani's platform of prudence and hope is a practical translation of the idea of dialogue among nations into the realm of politics. ${ }^{93}$ In addition to this, as was the case with Khatami's own 'dialogue among civilisations', he states that 'constructive engagement' and Rouhani's government of 'prudence and hope' are not just about diplomacy with the 'West'. Rather, a particular type of dialogue should be the foundation of constructive engagement: 'an emphasis on dialogue and mutual understanding globally'. ${ }^{94}$ In the framework of 'constructive engagement', Rouhani has been able to address the nuclear issue, the key to which, as noted at the beginning of this article, is the 'people'. For, as far as this member of Iran's ruling elite is concerned, without 'the people', Rouhani would not have been elected and this latest phase of the Islamic Republic would not have been 'of the people'. However, whether 'the people' perceive Rouhani in this manner is another issue entirely. Nevertheless, Rouhani has been a useful tool with which to restore the Islamic Republic's legacy of subalternity and add substance to its populist discourse.

\section{Conclusion}

Populist discourse is discourse that constitutes 'the people' as a popular subject in the context of a situation whereby an internal frontier is built that divides the social space into two camps $^{95}$. In this situation there is a 'relation of antagonism, ${ }^{96}$ whereby 'the people' (the 'self') are constructed as the 'underdogs ${ }^{97}$ in relation to a hegemonic 'other'. Importantly, 'the people', only exist in so far as they are constructed as such through the articulation of discourse. In the case of Iran, I have shown how a populist discourse is articulated by the Islamic Republic's ruling elites and how members of these ruling elites construct the Islamic Republic as 'the people'. In addition to this, I have also illustrated that embedded in this process of construction there is a particular historical experience that continues to give the regime legitimacy. This particular historical experience is Iran's 1979 Revolution. In this context, through the articulation of Khomeini's populist discourse, 'the people', constructed 
as the 'self', were in a relation of antagonism with the Pahlavi regime: the hegemonic 'other'.

The establishment of the Islamic Republic following the 1979 Revolution is an example of subaltern groups successfully overthrowing the state hegemon and establishing themselves as the hegemon because they had the 'national-popular collective will'. Thus, being the beholder of the 'national-popular collective will' symbolises the importance of the legacy of subalternity. The experience of subalternity prior to the 1979 Revolution is crucial in understanding the current Islamic Republic. This is because, for Gramsci, without the 'national-popular collective will', political transformation, or revolution, will not materialise. Indeed, as noted above, ultimately, revolution comes about when subaltern groups (Iranian masses) overthrow the hegemon (Pahlavi regime), and establish themselves as the new hegemon (the Islamic Republic), while maintaining the 'national-popular collective will'.

I would argue that while the position in society has changed, the populist discourse, while remaining fluid, is a discourse that has continued post-revolution. In this discourse, the Islamic Republic continues to construct itself as the beholder of the 'national-popular collective will'. Now there is essentially a post-subaltern hegemonic populism; a discourse that perceives itself as championing the 'nation-popular collective will' because of its legacy in the period leading to the 1979 Revolution and the establishment of Islamic Republic. This legacy of subalternity is crucial to understanding the Islamic Republic in terms of its perception of the 'self'. However, the 2009-10 popular uprisings suggested that the Islamic Republic's position as beholder of the 'national-popular collective will' was under threat. It has been illustrated that Rouhani's presidential candidacy is a means of restoring that 'national-popular collective will'. And, indeed, with Rouhani, the Islamic Republic has continued to articulate a populist discourse that constructs the 'self' as 'the people' despite no longer being a subaltern in domestic politics. Its legacy of subalternity continues to be embedded in this populist discourse.

By using a combination of the notion of populist discourse and Gramsci's 'nationalpopular collective will', I have tried to illustrate and highlight the importance of the legacy of subalternity. An appreciation of the legacy of subalternity allows for a deeper interrogation of how post-revolution governments perceive themselves and subsequently their relationship with 'the people' and the 'ruled'.

\section{Bibliography}

Abrahamian, Ervand. Iran between Two Revolutions. Princeton: Princeton University Press, 1982.

Abrahamian, Ervand. Khomeinism: Essays on the Islamic Republic, London: I. B. Tauris, 1993

Abtahi, Mohammad Ali. "Introduction." In Mardumsalari [Democracy]. Tehran: Tarh-i Naw Publishers, 1380/2001.

Ansari, Ali M. Confronting Iran. New York: Basic Books, 2006.

Ansari, Ali, M. Crisis of Authority: Iran's 2009 Presidential Election. London: Chatham

House, 2010. 
Ansari, Ali M. Islam, Iran and Democracy: The Politics of Managing Change. 2nd ed. London: Royal Institute of International Affairs, 2006

Ansari, Ali M. Modern Iran. 2nd ed. Harlow: Pearson Education, 2007.

Bayat, Asef. Making Islam Democratic: Social Movements and the Post-Islamist Turn.

Stanford, California: Stanford University Press, 2007.

Bozkurt, Umut. "Neoliberalism with a Human Face: Making Sense of the Justice and

Development Party's Neoliberal Populism in Turkey”, Science \& Society 77 no. 3 (2013):

372-396.

Canovan, Margaret. The People. Cambridge: Polity, 2005.

Canovan, Margaret. Populism. New York: Harcourt Brace Jovanovich, 1981.

Chehabi, Houchang E. "The political regime of the Islamic Republic of Iran in comparative perspective", Government and Opposition 36 no.1 (2001): 48-70.

Dabashi, Hamid. 2011. The Green Movement in Iran. Transaction Publishers, New

Brunswick and London

Dodson, Michael, and Manochehr Dorraj. "Populism and Foreign Policy in Venezuela and Iran." The Whitehead Journal of Diplomacy and International Relations 16 no. 1 (2008): 7187.

Ehsani, Kaveh, Arang Kesharvarzian, and Norma Claire Moruzzi. "Tehran, June 2009."

MERIP. Accessed February 9, 2015. http://www.merip.org/mero/mero062809

Ehteshami, Anoushiravan and Luciano Zaccara. "Reflections on Iran's 2013 Presidential

Elections", Orient IV no. 54 (2013).

https://www.academia.edu/4701146/Reflections_on_Iran_s_2013_Presidential_Elections

Elling, Rasmus Christian. Minorities in Iran: Nationalism and Ethnicity after Khomeini. New

York: Palgrave Macmillan, 2013.

Ellner, Steve. "Revolutionary and Non-Revolutionary Paths of Radical Populism: Directions of the Chavista Movement in Venezuela." Science \& Society 69 no. 2 (2005): 160-189.

Forgacs, David, ed. The Antonio Gramsci Reader: Selected Writings 1916-1935, New York:

New York University Press, 2000.

Gramsci, Antonio. Further Selections from the Prison Notebooks. Translated and edited by

Derek Boothman. London: Lawrence \& Wishart, 1995.

Gramsci, Antonio. Selections from the Prison Notebooks. . Translated and edited by Quintin

Hoare and Geoffrey Nowell-Smith. London: Lawrence and Wishart, 1971.

Green, Marcus. "Gramsci Cannot Speak: Presentations and Interpretations of Gramsci's Concept of the Subaltern." Rethinking Marxism 14 no. 3 (2002): 1-24.

Halliday, Fred. Islam and the Myth of Confrontation, New York, I. B. Tauris, 2003.

Hart, Gillian. "Gramsci, Geography and the Languages of Populism.” In Gramsci: Space, Nature, Politics, edited by Michael Ekers, Gillian Hart, Stefan Kipfer and Alex Loftus, 301320. Oxford: Wiley-Blackwell, 2013.

Harris, Kevan. "An "Electoral Uprising” in Iran." Middle East Research and Information Project July 19, 2013. Accessed October 19，2015: http://www.merip.org/mero/mero071913

Holliday, Shabnam J. "Contingent Subalternity in IR: The Case of Iran's Democracy Movement, the Green Movement." Paper presented at the annual British International Studies Association conference, London, June 16-19, 2015.

Holliday, Shabnam J. Defining Iran: Politics of Resistance, Farnham: Ashgate Publishing, 2011. 
Holliday, Shabnam J. "Iran's Own Uprising and the Arab Spring." In Routledge Handbook of the Arab Spring edited by Larbi Sadiki, 526-536. London: Routledge, 2015.

Holliday. Shabnam J. and Rivetti, Paola. "Divided we stand? The Heterogeneous Political Identities of Iran's 2009-10 Uprisings." In Political Identities and Popular Uprisings in the Middle East edited by Shabnam J. Holliday and Philip Leech. Rowman and Littlefield International, 2016.

Howarth, David. "Populism or Popular Democracy? The UDF, Workerism and the Struggle for Radical Democracy in South Africa." In Populism and the Mirror of Democracy edited by Francisco Panizza, 202-223. London and New York: Verso, 2005.

Braunschweiger, Amy. "Interview: Yes, Iran does have political prisoners." Human Rights Watch. Accessed July 21, 2015.

http://features.hrw.org/features/Interview_Yes_Iran_does_have_political_prisoners/index.ht $\mathrm{ml}$ ?_ga=1.268027598.1981648143.1437483040

Ionescu, Ghiţa and Ernest Gellner, eds. Populism: Its Meanings and National Characteristics. London: Weidenfield and Nicolson, 1969.

Jahanbegloo, Ramin, ed. Iran: Between Tradition and Modernity. Oxford: Lexington Books, 2004.

Kamrava, Mehran, and Hassan-Yari, Houchang. "Suspended equilibrium in Iran's political system." The Muslim World 94 no.4 (2004): 495-524.

Keddie, Nikki. Modern Iran: Roots and Results of Revolution. New Haven \& London: Yale University Press, 2003.

Keshavarzian, Arang. "Contestation without Democracy: Elite Fragmentation in Iran." In Authoritarianism in the Middle East: Regimes and Resistance edited by Marsha Pripstein Posusney and Michele Penner Angrist. Boulder, Colorado: Lynne Rienner Publishers, 2005. Khamenei, S.A. Pursish va pasukh az mahzar-i Rahbar-i Mu 'azam-i Inqilab-i Islami Hizarat-i Ayatollah Aluzma Khamene' $i$ [Question and Answer in the presence of the Supreme Leader Grand Ayatollah Khamene'i]. Tehran: Mu'assasih-yi Farhangi-yi Qadr-i Vilayat, 1380/2001-2002.

Khamenei, S.A. "Leader Addresses Nation in Friday Prayers: Transcript, 19 June 2009”. Accessed June 30, 2015. http://www.juancole.com/2009/06/supreme-leader-khameneisfriday-address.html.

Khamenei, S.A. "Khutbih-ha-yi Namaz-i Jum'i-yi Tihran, 29 Khurdad 1388 (19 June 2009)". Accessed June 30, 2015. http://farsi.khamenei.ir/speech-content?id=7190.

Khamenei, S.A. 'Khamenei 8/26 on 'Soft War,' Trials, Errors, Foreign Role, 27 August 2009”. Accessed: June 30, 2015.

http://www.iranalmanac.com/news/lastnews.php?newsid=11187.

Khatami, Mohammad. "Iran: This Time, the West must not Turn its Back on Diplomacy." The Guardian. Accessed January 12, 2015.

http://www.theguardian.com/commentisfree/2013/sep/23/iran-west-not-turn-back-diplomacy Laclau, Ernesto. On Populist Reason. London: Verso Books, 2002.

Laclau, Ernesto. "Populism: What's in a Name?" In Populism and the Mirror of Democracy edited by Francisco Panizza, 32-59. London \& New York: Verso, 2005.

Laclau, Ernesto and Chantal Mouffe. Hegemony and Socialist Strategy: Towards a Radical Democratic Politics, London: Verso, 1985.

Menashri, David. "Hassan Rouhani: Iran's New Hope for Change.” Strategic Assessment 16 no. 2 (2013): 7-21.

Martin, Vanessa. Creating an Islamic State. 2nd ed. London: I. B. Tauris, 2003. 
Mebane, W. R. "Note on the Presidential Election in Iran, June 2009." Umich.edu. http://www-personal.umich.edu/ wmebane/note24jun2009.pdf

Minogue, Kenneth. "Populism as a Political Movement." In Populism: its meanings and national characteristics edited by Ghiţa Ionescu and Ernest Gellner, 197-211. London: Weidenfield and Nicolson, 1969.

Moin, Baqer. Khomeini. Life of the Ayatollah. London: I. B. Tauris, 2009.

Monshipouri, Mahmood and Manochehr Dorraj. "Iran's Foreign Strategy: A Shifting Landscape.” Middle East Policy XX no. 4 (2013): 133-147

Moslem, Mehdi. Factional Politics in post-Khomeini Iran. Syracuse, New York: Syracuse University Press, 2002.

Netanyahu, Benjamin. "Transcript of Netanyahu's UN General Assembly speech.” Haaretz. Accessed July 21, 2015. http://www.haaretz.com/news/diplomacy-defense/1.550012

Panizza, Francisco. "Introduction." In Populism and the Mirror of Democracy edited by Francisco Panizza, 1-31. London and New York: Verso, 2005.

Ray, Larry. "'Fundamentalism', Modernity and the New Jacobins." Economy and Society 28 no. 2 (1999): 198-221.

Rouhani, Hassan. "Avalin Nishist-i Khabari-yi Ra'is Jumhur-i Muntakhib, 27 Khurdad 1392” [The First Press Conference of the Elected President of the Republic, 17 June 2013]. President.ir. Accessed July 21, 2015. http://www.president.ir/fa/70006.

Rouhani, Hassan. "Matn-i kamil- Guftugu-yi Shabakih-i Tilivizioni NBC Amrika ba Duktur Rouhani, 29 Sharivar 1392" [Full Text of America's NBC Network Interview with Dr Rouhani, 20 September 2013]. President.ir. http://www.president.ir/fa/71342.

Rouhani, Hassan. "Matn-i Kamil-i Guzarish-i 100 Ruzih-yi Ra'is Jumhur dar Guftugu-yi Tiliviziyoni, 6 Azar 1392" [Full Text of the 100 Day Report of the President in a Television Interview, 27 November 2013]. President.ir. Accessed April 28, 2014.

http://www.president.ir/fa/72988.

Rouhani, Hassan. "Matn-i Kamil-i Sukhanan-i Duktur-i Rouhani dar Marasim-i Tanfidh-i Hukm-i Riyasat-i Jumhuri az suy-i Rahbar-i Mu'zam-i Inqilab, 13 Murdad, 1392." [Full Text of the Speech of Dr Rouhani at the Confirmation Session of the Rule of the Republic's President in the Presence of the Supreme Leader, 4 August 2013]. President.ir. Accessed July 21, 2015. http://www.president.ir/fa/70471.

Rouhani, Hassan. "Transcript of Ann Curry's Interview with Iranian President Hassan Rouhani." NBC. Accessed April 28, 2014.

http://www.nbcnews.com/id/53069733/ns/world_news-mideast_n_africa/t/full-transcript-anncurrys-interview-iranian-president-hassan-rouhani/\#.U14_sFdN3yU

Saleh, Alam. Ethnic Identity and the State in Iran. New York: Palgrave Macmillan, 2013. San Juan, Epifanio. "Gramsci's theory of national-popular." In Perspectives on Gramsci: Politics, Culture and Social Theory edited by Joseph Francese, 163-185. London \& New York: Routledge, 2009.

Sherrill, Clifton W. "Why Hassan Rouhani won Iran's 2013 Presidential Election.” Middle East Policy XXI no. 2 (2014): 64-75.

Shils, Edward. The Torment of Secrecy: The Background and Consequences of American Security Policies. London: Heinemann, 1956.

Stavrakakis, Yannis. "Religion and Populism in Contemporary Greece." In Populism and the Mirror of Democracy edited by Francisco Panizza, 224-249. London \& New York: Verso, 2005.

Taggart, Paul A. Populism. Open University Press, 2000.

Tazmini, Ghoncheh. Khatami's Iran: The Islamic Republic and the Turbulent Path to Reform. London: I. B. Tauris, 2009. 


\section{Worsley, Peter. "The Concept of Populism.” In Populism: Its Meanings and National Characteristics edited by Ghiţa Ionescu and Ernest Gellner, 212-250. London: Weidenfield and Nicolson, 1969.}

\section{Notes}

${ }^{1}$ Khamenei, Pursish va Pasukh [Question and Answer], 58-9.

${ }^{2}$ Rouhani, Matn-i Kamil-i Guzarish-i 100 [Full Text of the 100 Day Report].

${ }^{3}$ The Gregorian calendar is not usually used in Iran. Therefore the Iranian publication date is given with the Gregorian equivalent. When a text is available in both Persian and English both references are given.

${ }^{4}$ Rouhani, Matn-i Kamil-i Guzarish-i 100 [Full Text of the 100 Day Report].

${ }^{5}$ The term elite is understood as those who have been or are part of the Islamic Republic leadership apparatus.

${ }^{6}$ The International Journal of Middle Eastern Studies transliteration system excluding diacritical marks is used here.

${ }^{7}$ At the time of the election the three presidential candidates, Mir-Hossein Mousavi, Mehdi Karoubi and Mohsen Rezai argued that there was evidence of electoral fraud (see Ansari, Crisis of Authority, 5). In this context several reports were published that also out forward this argument (see Mebane, Note on Presidential; Ehsani et al. Tehran). Ansari (Crisis of Authority) argues that the evidence for fraud in the election is persuasive.

${ }^{8}$ Ansari states that 'the size of the crowds in 2009 is comparable to, if not larger than' those of Ashura 1978 before the 1979 Revolution (Ansari, Crisis of Authority, 4)

${ }^{9}$ Ansari, Crisis of Authority, 12

${ }^{10}$ Ehteshami and Zaccara, "Reflections", 7.

${ }^{11}$ Sherrill. "Hassan Rouhani", 70.

12 Menashri, "Hassan Rouhani", 8.

${ }^{13}$ Ehteshami and Zaccara, "Reflections", 7;

${ }^{14}$ Sherrill. "Hassan Rouhani", 65.

${ }^{15}$ Ibid., 65.

${ }^{16}$ Monshipouri and Dorraj, “Iran's Foreign Policy”, 134.

${ }^{17}$ Ibid.

${ }^{18}$ Ehteshami and Zaccara, "Reflections", 12; $72.2 \%$ of the 50 million eligible to vote voted.

${ }^{19}$ Harris, "Electoral Uprising"; see also Ehteshami and Zaccara, "Reflections", 12 for a breakdown of votes per province and votes per candidate.

${ }^{20}$ Harris "Electoral Uprising"; also see Harris (2013) for an analysis of the political manoeuvring leading up to the 2013 election.

${ }^{21}$ Monshipouri and Dorraj, "Iran's Foreign Policy", 134.

${ }^{22}$ See Saleh, Ethnic Identity and Elling, Minorities in Iran for recent in-depth analyses of ethnicity in Iran.

${ }^{23}$ See Holliday and Rivetti, "Divided we stand?"

${ }^{24}$ Chehabi, "The political regime"; Kamrava and Hassan-Yari, "Suspended equilibrium"; Keshavarzian, "Contestation without Democracy"; Moslem, Factional Politics.

${ }^{25}$ Ionescu and Gellner, Populism; Laclau, On Populist Reason; Panizza, Populism and the Mirror of

Democracy; Stavrakakis, 'Religion and Populism'; Canovan, Populism; Canovan, The People; Taggart, Populism.

${ }^{26}$ Minogue, 'Populism'; Ellner, 'Revolutionary'; Abrahamian, Khomeinism; Dodson and Dorraj, 'Populism and Foreign'; Bozkurt, 'Neoliberalism'.

${ }^{27}$ Howarth, 'Populism or Popular Democracy'; Panizza, Populism; Stavrakakis, 'Religion and Populism'

${ }^{28}$ Laclau, On Populist Reason, 17.

${ }^{29}$ Ibid., 12-13.

${ }^{30}$ Laclau, 'Populism'.

${ }^{31}$ Laclau, On Populist Reason, 16.

${ }^{32}$ Laclau, 'Populism'.

33 Ibid., 68.

${ }^{34}$ Shils, The Torment of Secrecy; Worsley, 'The Concept of Populism'; Panizza, Populism; Laclau, 'Populism'.

${ }^{35}$ Panizza, Populism, 3.

${ }^{36}$ Laclau, 'Populism', 43.

${ }^{37}$ Ibid.

${ }^{38}$ Panizza, Populism, 3.

${ }^{39}$ Ibid. 


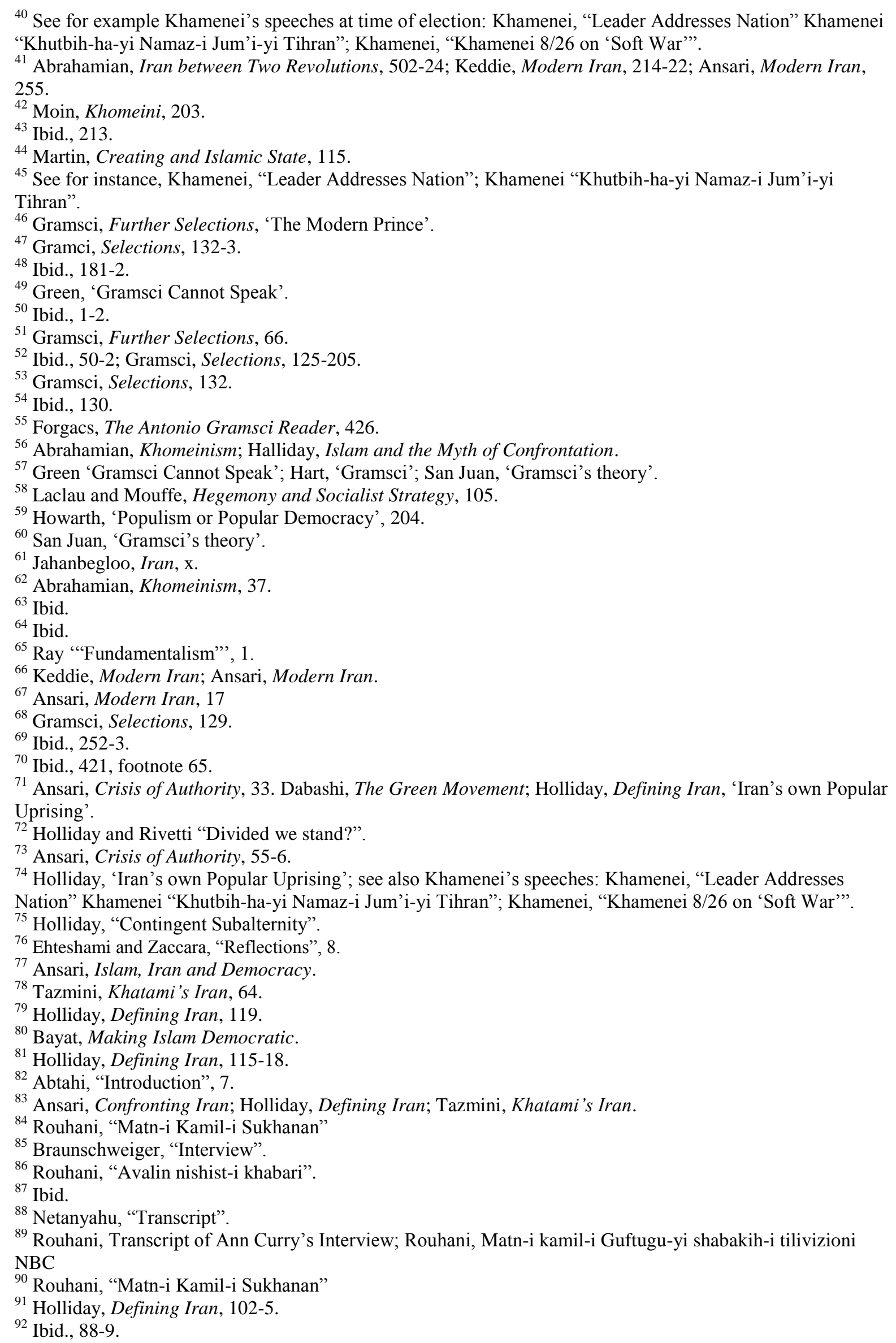


93 Khatami, 'Iran'.

${ }^{94}$ Ibid., my emphasis; see Holliday, Defining Iran, 113-4.

${ }^{95}$ Laclau, 'Populism', 43.

${ }^{96}$ Panizza, Populism, 3.

${ }^{97}$ Ibid. 